\title{
The Life of a Provincial Musician in Late Nineteenth-Century New Zealand: A Case Study of Joseph Higham in Hawera
}

\author{
PHILIP JANE
}

\begin{abstract}
There has been little research into musical endeavour in small rural New Zealand townships during the late nineteenth century. This article explores the life of Joseph Higham, one of the first professional musicians to settle long term in Hawera. It surveys his wide-ranging musical activities in and around Hawera, including his relationship with the Roman Catholic Church. The work, influence and outcomes of provincial musicians are compared to musicians working in the larger cities; while the reduced scale of amateur activities resulting from a smaller and more widespread population is notable, the general quality and professionalism of teaching is similar.
\end{abstract}

\section{Introduction}

Emigrants, mainly from Britain or Europe, brought with them traditions of church music, teaching methodologies, domestic music and musical theatre, establishing a musical culture that supported professional musicians in nineteenth-century New Zealand. ${ }^{1}$ The larger populations of the four main centres supported the development of extensive teaching practices, and provided scope to form and lead other paid musical activities such as choral, orchestral and operatic groups. Even so, central to a successful career was the acquisition of an organist position in one of the large Protestant churches. There have been numerous studies about musicians and musical activity in the four main centres of New Zealand in the late nineteenth century. Christchurch, for example, is well served with an overall historical survey; a study of the role of music in the Anglican Church; the sociology of local choral societies; a survey of orchestral activity; and the work of an individual professional musician. ${ }^{2}$ There has, however, been little research into the progress of musical endeavour in small rural townships during the same time period. ${ }^{3}$ This paper is a study of the life of Joseph Higham, one of the first professional musicians to settle long term in Hawera. It examines his wide-ranging musical activities in Hawera, including the role the Roman Catholic church played in his professional and personal life, and acknowledges the significant yet neglected role such musicians played in creating the fabric of musical life in provincial towns throughout New Zealand. Higham died in 1931, and the musical activity in Hawera in the period after his death has been extensively studied and documented by Allan Thomas, in particular with a snapshot of the year $1946 .{ }^{4}$ In the absence of any primary source materials, contemporary newspapers form the major source of this study.

As noted in 1922 in the local Hawera newspaper, "The history of music in Hawera, as in most provincial towns, has been somewhat spasmodic. Nearly every society has depended on a few enthusiasts, and when through departure or other cause these have been found wanting the society has suffered." "The local music teacher Joseph Higham represents one such enthusiastic individual. Styling himself "Professor of Music," he settled near Hawera in 1889, having previously been active in New Plymouth since early 1887 . He remained resident in and around Hawera for the next forty-two years, and during a great part of this time was a leader in music circles. ${ }^{6}$ His story is notable as he was neither a keyboard musician, nor of the Anglican faith attributes that generally accorded an individual more success in a musical career in colonialsettler nineteenth-century New Zealand. By the time of his death in 1931, it was said that 
Hawera, for its size, must have been one of the most musical towns in the Dominion. ${ }^{7}$ In addition to a flourishing amateur musical culture, it was supported by a number of highly professional and productive music teachers.

\section{Joseph Higham}

Joseph Higham was born 13 April 1858 at Wigan, near Manchester in England. He was the fourth son in a family of five boys and one girl. His father was John Higham, who at the time of Joseph's birth was a labourer in a local foundry, and his mother was Ellen Higham, née Walmsley. Along with his education at St. Patrick's School in Wigan, Joseph received an initial musical education in theory and singing from his father, who by then had become a music teacher. ${ }^{8}$ It was a family with a long tradition of musical activity; his father, grandfather, greatgrandfather, and two of his brothers were church choirmasters. ${ }^{9}$ Following further violin tuition and training in choral singing, Joseph spent time as an orchestral violinist in Chester and Liverpool before he departed for Australia in $1884 .{ }^{10}$ Little is known of his whereabouts or activity during the time he spent in Australia.

Higham arrived in New Plymouth in 1887, and his first recorded instance of music activity was in April as the viola player in the orchestra for an amateur production of HMS Pinafore. ${ }^{11}$ Then in August he took part in a concert in the Alexandra Hall to raise funds for a new Catholic church building. On this occasion he demonstrated the breadth of his musical versatility, taking part as a singer in a glee group, performing a violin solo and being a member of an instrumental trio, and conducting some items. ${ }^{12}$ From this auspicious start, he maintained a high profile as a musician in New Plymouth, performing as a violinist in other local operatic productions, singing in fund-raising concerts, conducting where required, and serving as choirmaster at the local Catholic Church, St. Joseph's. ${ }^{13}$ Indeed, throughout his musical career, Higham was notable for the professional and personal support he gave to the Catholic church, not only directly, as worshipper, choirmaster and performer at services, but as a regular and enthusiastic participant at fund-raising ventures. ${ }^{14}$

By 1888 he was entrenched as a respected musician in the town; always readily available for concerts as singer or violinist, and with a growing reputation as a conductor. Additionally, he had expertise in a wide range of instruments and areas of music, and taught theory, singing, violin, viola, cello, and the slide trombone, as well as offering services as a pianoforte and organ tuner. ${ }^{15}$ At the same time, his talents as a composer were being recognised, with a number of performances by local brass bands of two of his compositions, the marches "Defiance" and "Zealandia." He also composed music for performance at the services of the Catholic Church. In March he demonstrated yet another aspect of his musical talents with the inaugural issue of a new music magazine, The Colonial Brass and Military Band Journal. ${ }^{16}$ In addition to this already extensive list of activity, he then attempted to form a choral group to perform selections from William Wallace's opera Maritana. Unfortunately, he was forced to abandon this enterprise as he was unable to assemble a suitable balance of voices. ${ }^{17} \mathrm{He}$ was successful though in resurrecting a defunct orchestral association, and the invigorated Taranaki Philharmonic Society gave its first concert on 25 October with an orchestra of eleven players. It was deemed a splendid success, with a special word of praise for Higham's conducting. ${ }^{18}$ Another concert was given by the Society in late December, and Higham again came in for praise in bringing the society to a high pitch of excellence. ${ }^{19}$ Despite a seemingly successful and growing music practice in New Plymouth, Higham departed the town in January 1889. He was reported to be on his way to settle in Wellington, but ended up living near Hawera. ${ }^{20}$ 
Hawera is situated near Mount Taranaki in the North Island of New Zealand, seventy kilometres south-east of New Plymouth, and eighty-nine kilometres north of Wanganui. It grew as a settlement around a blockhouse constructed in 1870 to house government military troops, and was a much smaller settlement than New Plymouth, but with numerous townships nearby. ${ }^{21}$ Both Opunake and Waverley are situated the furthest away from Hawera, yet still within a fifty kilometre radius, while Stratford, Kaponga and Patea are each around thirty kilometres distant. The four towns of Eltham, Manaia, Okaiawa and Normanby are only a few kilometres from Hawera. The proximity of small townships was important for potential concert venues and audiences, as well as increasing the catchment pool for pupils. Indeed, for a number of years Higham was resident in Ngaire, some forty kilometres from Hawera, and during this period he made weekly trips to Hawera, where on Saturdays he provided music instruction. ${ }^{22}$ Even when settled in Hawera he continued to make weekly teaching visits to nearby outlying townships.

Although a relatively new and small settlement, music was not neglected as part of the town's development with the formation of a brass band in 1878 and a choral society in $1880 .{ }^{23}$ A town hall was built in 1878, providing a venue for musical performances. Sited originally in the centre of the town, on the corner of High and Princes streets, it had numerous additions and alterations to accommodate growing demand and was renamed the Opera House in $1896 .{ }^{24}$ Another performance venue, the Theatre Royal, was built in 1896 by a local businessman, Edward Cullinan, and offered seating to a thousand people. ${ }^{25}$

\section{Music Teaching}

Teaching music was generally the primary source of income for a professional musician like Higham, and early Hawera did not have many long-term resident music teachers prior to his arrival in 1889. This was to be expected in a newly settled rural area with a small scattered population, and where most occupations were devoted to clearing and establishing farms or the service industries required in support of agriculture. Frederick Sparks resided in nearby Patea from 1877 onwards, and he included regular visits to Hawera as part of his teaching practice. ${ }^{26}$ He was followed to Hawera by Leslie Charles (1880-1881), Henry Homeyer (1881), and Bernard Homberg (1882-1884). ${ }^{27}$ They all found that despite additional income from performing at social events or balls, and tuning pianos and organs, there was not enough support to retain them within Hawera for very long.

There were two other musicians active in Hawera before Higham arrived who both remained for nearly twenty years. The first was Catherine Swinburne, who arrived in 1883 when her husband Walter was appointed manager of the Hawera branch of the Taranaki Co-operative Store. She offered tuition in music and singing, as well as taking a full part in local music events, including a leading role in annual amateur operatic productions. She left Hawera in $1900{ }^{28}$ The second was Annie Palmer, an unmarried woman of twenty-four when first noted in Hawera in 1884. She taught music, was the regular accompanist at most concert occasions, was the organist at St. Mary's Anglican Church for twenty years, and left for Nelson in $1906{ }^{29}$ It is possible that Swinburne received her musical training in England where she was born, but there is no evidence to indicate what form this may have taken. Palmer appears to have learnt her skills from her mother, probably aided by an aunt, Clara Straker. Neither claimed any advanced training from a recognised musical institution.

Higham initially offered tuition in all string and brass instruments, theory and singing, as well as tuning pianos and organs, and by 1893 he appears to have dominated music teaching in Hawera. There were a few other music teachers available in the outlying areas of Ngaire and Pihama, as well as in Hawera, but they appear to have been teachers of only the piano. The 
arrival of Lucy Harrison in 1893 briefly added another teacher of violin. ${ }^{30}$ Throughout his teaching career in Hawera, Higham continued to expand the number of instruments he taught. In addition to "all string and brass instruments" he gradually added the clarinet and flute, and, as certain instruments became more popular, he assimilated the required skills and by 1924 had added mandolin, banjo, guitar, steel guitar and ukulele. ${ }^{31}$ In 1896 he moved from teaching rooms in High Street to a purpose-built house in Union Street which contained an additional large room for his music teaching activities, and was big enough to accommodate orchestral meetings and rehearsals. ${ }^{32}$

From Higham's arrival onwards, though, the number of professional musicians in Hawera steadily increased and can be divided into three groups. First, those who arrived as fully functioning musicians and who had chosen the area to work in. Along with Higham, this group is represented mainly by the organist or choirmaster employed at the local churches. ${ }^{33}$ For a number of these later arrivals, Hawera was merely a stepping stone on their professional career as a church organist, as they moved frequently from position to position throughout New Zealand. ${ }^{34}$ Many in this group came with qualifications from either the Associated Board of the Royal Schools of Music or Trinity College of Music, London.

Richard Lavars Hutchens arrived in the district in late 1893, and became a full-time music teacher in $1898 .{ }^{35}$ His background was not as a keyboard musician, but focussed upon choral work, especially in the Wesleyan Church. His teaching was the basis for the musical careers of his three children, of whom the youngest, Frank, is possibly the most well-known musician of international standing to come from Hawera. He should not be remembered only for the outstanding musical abilities of children, but also for his long-term role as a professional musician in Hawera, which he, like Higham, centred around his church activity and teaching practice.

Harry C. A. Fox arrived in Hawera in 1924, in response to the very generous annual salary of $£ 200$, to be conductor of the Hawera Municipal Band. ${ }^{36}$ His background and expertise was not as a keyboard musician, but as a bandmaster and conductor, although his influence was certainly not limited to this single area. Of the generation after Higham, he was the musician most influential in building the reputation of Hawera as the most musical town in New Zealand. His time spent at Hawera High School as bandmaster and orchestra conductor from 1929 onwards was particularly fruitful.

The second group of musicians were those who arrived as fully functioning musicians, but for whom Hawera was a destination for non-musical reasons. Some, like Swinburne and Minnie Roe, came because of their husbands' work. ${ }^{37}$ Others, including Eleanor Edwards and Daisy Reilly arrived when their family moved to the area. ${ }^{38}$ And Mary King, the wife of an early settler, took up music teaching after the death of her husband. ${ }^{39}$ It should be stressed that notwithstanding the reasons for settling in Hawera, the quality and standard of professionalism demonstrated by those in this second group was in no way inferior to those of the first.

Within each of these two groups, only a small number were teachers who claimed overseas qualifications. ${ }^{40}$ For those without the tangible signs of degrees or diplomas, their initial acceptance was based upon publicly demonstrated ability, which was confirmed as their teaching ability produced excellent results.

The third group of music teachers were those who grew into a level of competence qualifying them to teach. They lived in the immediate area of Hawera, and their musical expertise was 
based upon the tuition they had received from locally based teachers. This group includes Annie Quin (née Flynn); Violet Robinson; Eunice Morrieson (née Johnson), and Ivy McCarty (née Robinson). ${ }^{41}$ Of the resources used by music teachers, there was an increasing use of graded music exams, which had been introduced to New Zealand by the Trinity College, London, in 1888, and the Associated Board in 1897. Both institutions added professional diplomas in 1899, and many who came to teaching did so with the backing of a professional diploma gained in New Zealand. ${ }^{42}$ A small number of students advanced to further study overseas. ${ }^{43}$

Music was also taught in local schools, and in some cases this involved a teacher dedicated to the subject, for example at a private school run by Miss Hazelden, and St. Mary's Anglican School for girls. ${ }^{44}$ A large number of Hawera girls went to St. Mary's convent in Wellington, others to convents in Patea, Manaia, New Plymouth, and even as far away as Sacred Heart Convent, Timaru. ${ }^{45}$ Many of the students who progressed from a local teacher in Hawera to a teacher attached to a convent school in a city were demonstrating their serious musical aspirations. ${ }^{46}$ But it was at the local high school, which was reconfigured to a Technical High School in 1919, where music teaching showed the strongest development. This was under the direction of Harry Fox as he fostered three school bands and orchestras, along with a junior band for boys.

Hawera appears no different to the four main centres in the manner in which music teachers arrived. But in contrast to the four main centres, which attracted and retained many from the Continent, there was a total dominance in Hawera by those with an English background and training. ${ }^{47}$ Options pursued for future musical study by those in early Hawera were a reflection of what had been the case for their teachers; an overwhelming support for the English schools and style. As Kirstine Moffat states,

hierarchies [were] at work in the colonial teaching profession. New Zealand-trained teachers usually introduced pupils to the piano and taught in the smaller towns and rural areas. Students with serious musical aspirations progressed to study with expensive teachers based in the larger centres, who had British or European training and a performance profile. ... [L]ocal teachers tended to be women, while many of the respected, more expensive, city teachers were men. ${ }^{48}$

Music teachers' income came from the fees charged, and those for individual music lessons appear to have commonly been two guineas per quarter from 1887 onwards. ${ }^{49}$ This was the case in both Hawera and Christchurch, for example, although Christchurch additionally had a top tier of elite teachers who commanded much higher fees. ${ }^{50}$ The range of instruments taught in Hawera was comparable to those in the cities; mainly piano, organ, singing and associated theoretical aspects of music. But as was demonstrated by Higham, teachers often expanded and accommodated their skills to whatever brought in pupils. Notwithstanding the smaller scale of music teaching in Hawera, in scope and depth it was comparable to the cities. The quality of the teaching was reflected by the relatively large numbers from Hawera who went on to musical careers, either locally, New Zealand-wide, or overseas.

\section{Church Activity}

Another important facet of a professional musician's livelihood was the certainty given by employment in a church. At this time, organists and choirmasters in the larger Anglican churches could earn between $£ 50$ to $£ 200$ per annum. ${ }^{51}$ Indeed, as Helen Watson in her master's thesis notes, "The means of livelihood for a musician in the first thirty to forty years of the colony were so meagre, that the salary offered by the church to the choirmaster and organist was eagerly sought after." 52 Payment in Hawera was on a much smaller scale; $£ 20$ per annum 
for positions in the Anglican and Presbyterian churches in 1912, rising to $£ 65$ in the Presbyterian church by 1915 . Yet this was similar to the salaries of the smaller churches in the main centres. ${ }^{53}$ While there were long-term incumbents for organist roles in Hawera in the late nineteenth century, in the early twentieth century there were numerous short-term appointments as the churches acquired better and larger organs and attracted professional organists. Even so, during the tenure of the professional organists, they were active as music teachers in the community.

The musical situation in Roman Catholic churches was different. Here, the usual combination of organ and choral forces was enhanced by the regular use of orchestral resources, and the role of the organist was not of such a high profile. As in New Plymouth, Higham immediately played a leading role in music with the local Catholic Church, St. Joseph's, and became choirmaster in 1889. ${ }^{54}$ His early work with the choir saw masses by Haydn, Mozart and Weber performed regularly, and a rise in the size of the congregation at this time was directly attributed to the increased quality of music in the services. ${ }^{55} \mathrm{He}$ was able to utilise a balanced choir of four parts, with between ten to twelve voices regularly available. Using instrumentalists from within the congregation, he formed orchestral groups to accompany the choir on special occasions, such as an orchestra of five players (organ, two cornets, a double bass and a violin) for Christmas of 1892, while for Easter of 1897 he gathered together an even larger orchestra of twelve players. ${ }^{56}$

There were three families from the congregation of St. Joseph's who provided the bulk of the choir members and the orchestra when needed. The Flynn family was led from the front by the mother, Mary Jane, who in addition to being active in the church choir, formed the Flynn Family Orchestra from her ten children. Each child was able to play at least two instruments, and the oldest daughter, Annie, was the organist for the church. ${ }^{57}$ In the choir, Mary Jane Flynn was a soprano, with her daughters Katie and Nellie singing alto. At the Easter service in 1897, the orchestra used to accompany the music included seven of this family; James and Thomas (violins); Bessie (viola); Jack (clarinet); Katie (cello), Annie (double bass); and Nellie (piano and organ). The Connell family was likewise endowed with ten children, seven girls and three boys, and the four oldest, Katie, Nellie (Helen), Winnie (Mary Winifred) and Jessie, all joined their mother as regular members of the choir. ${ }^{58}$ And the local draper, Austin Joseph Whittaker, along with his wife were both choir members during Higham's time at St. Joseph's. From their family of two boys and six girls, their second son, Leo, was one of the organists to succeed Annie Flynn following her marriage. ${ }^{59}$ All of the children from these families were pupils at the Convent of the Holy Infancy, the school attached to St. Joseph's, Hawera. ${ }^{60}$

Higham was very enthusiastic about sharing his musical resources with the wider Catholic congregation, and he took the choir to perform at the opening of Catholic churches in Waverley (1889), Stratford (1894), Opunake (1895), Eltham (1898), and Manaia (1900). ${ }^{61} \mathrm{He}$ then returned to New Plymouth in 1895 for the opening of St. Joseph's new building, taking with him on this occasion a choir of twelve voices, and an orchestra of eight players. ${ }^{62}$ His work with the choir in Hawera raised the standard to where it was seen as "a credit to the town ... [and] visitors had stated that it compared most favorably with any outside the cathedral towns, and would be no disgrace to any of the big cities." ${ }^{\prime 63} \mathrm{He}$ was very popular in this role and received a number of gifts as tokens of appreciation: a gold watch and pendant (1892), an ebony baton mounted in silver (1895), a diamond ring (1896), and later, on the occasion of his marriage, a solid silver tea service, and a carved overmantel (1901). ${ }^{64}$ Indeed, his working method was seen as being a major contributor to the choir's success: "The members of the choir worked amicably, as a result of the efforts of Mr Higham, who judiciously blended mildness with firmness." ${ }^{65}$ Membership of the choir became keenly sought after, and when Katie Connell and 
Catherine Espagne married in 1903, their places in the St. Joseph's Choir were taken up by recent arrivals to Hawera, the music teacher Daisy Reilly and her sister Connie. ${ }^{66}$

Higham resigned as Choirmaster at St. Joseph's in 1904, after fifteen years in the role. ${ }^{67}$ Ostensibly his departure was because of increasing demand upon his services "owing to professional engagements," and his departure was received with unqualified regret and with generous acknowledgment of the artistic merit of his compositions. ${ }^{68}$ His resignation, though, was most likely a reaction to a motu proprio promulgated on November 22, 1903 by Pope Pius $\mathrm{X}$. This "Tra le Sollecitudini"-_"Instruction on Sacred Music"-announced a return to the Gregorian chant in ecclesiastical music. Amongst other actions it banned the use of the piano in churches, did not allow women to be part of the choir, prohibited the presence of bands in the church, and allowed the use of wind instruments only with special consent. ${ }^{69}$ All of these changes effectively stopped Higham from continuing to produce the style of music he had built up in the church over the years. It was a form of music he had contributed to with his own compositions, including "O Salutaris" and "Litany" (1896) and "Tantum Ergo" (1897).

The role carried out by Higham in Hawera was similar to the role carried out in St. Mary's Cathedral in Wellington in the 1890s, where there was an organist, a conductor/choirmaster and a leader of the orchestra. ${ }^{70}$ Yet another point of difference with the Anglican, Presbyterian and Wesleyan churches was the frequent appearance of musicians from touring opera companies. This occurred in Hawera, where two singers from Pollard's Opera Company assisted with the performance of Weber's Mass in G in $1896,{ }^{71}$ and in Wellington at St. Mary of the Angels', where members of the Williamson Musgrove Opera Company (1895), the Williamson Opera Company (1902), and Pollard's Opera Company (1902) assisted in presenting performances of classical music as part of the service. ${ }^{72}$ The practice of incidental music in addition to the music used for worship, plus the concertising from imported professionals, may have been part of what the "Tra le Sollecitudini" of 1903 aimed to curtail, in order to restore central importance of the liturgy and worship in the church. After 1903, the music at St. Joseph's, Hawera was less ambitious and noteworthy. At Christmas 1910, Higham returned to conduct the choir, while Daisy Reilly was the organist, but from 1912 onwards, the St. Joseph's Choir was under the direction of Daisy Reilly. ${ }^{73}$

\section{Orchestral}

Prior to Higham's arrival, there had been very little in the way of substantial orchestral activity. In the area surrounding Hawera, the earliest instance of a group accorded the term "orchestra" was noted in 1877, with four players at Patea comprising a piano, violin, cornopean and flute. ${ }^{74}$ This was a fairly typical heterogeneous band of the time, and such groups were to be found throughout New Zealand towns and cities. By 1883, though, the activity of the Patea Harmonic Society was felt to be labouring under the disadvantage of having no orchestra available, through a dearth of any string players. This was stated to be a direct result of no teacher of string instruments being available locally. ${ }^{75}$ The same situation prevailed in Hawera, and was adversely commented on at performances of the Hawera Harmonic Society in 1884, and again for the Hawera Choral Society in 1887. Within a short time of his arrival in Hawera, Higham formed an orchestral society, and from a concert given on 28 November 1890 it was noted that "the performance was of unusual excellence and would have done credit to any large town in the colonies. Mr. Higham, the conductor, is to be congratulated on the proficiency the orchestra has attained under his leadership." 76 The following year he gathered together a small orchestra of nine players at Ngaire. ${ }^{77}$ 
In May 1893, a week-long industrial exhibition was held in aid of the Hawera District Hospital Building Fund, and on this occasion Higham conducted the local orchestral society of thirteen players, and the choral musical society for two performances of an "Ode" he had composed for the occasion. ${ }^{78}$ Unfortunately, this society appears to have gone into abeyance after the exhibition, and from then on ad hoc groups were used to support other events.

Like most music teachers, Higham used the musical talents of his pupils to present concerts. This was a good form of advertising, especially when they were to raise funds for a worthy cause. In December 1893, the inhabitants of Hawera were advised that a rather unusual orchestra was being formed. Comprising 12 players - eight violins, one each of cello, double bass, cornet and piano - it was unusual in being an all-female group: the Hawera Ladies' Orchestra. ${ }^{79}$ It gave its first concert in April 1894, and over the next two years gave a total of five concerts. Each concert presented a different combination of people and instruments, but it remained basically a string group with some brass instruments when available. Initial comment was very positive,

The playing was marked by precision, and the strictest attention was paid to the piano and forte passages. The inclusion of a few reed instruments, and perhaps one or two brass instruments, will strengthen the orchestra in a marked degree; and it is probable, we understand, that such instruments will be added before the next concert. On the whole, the performance of the orchestra was full of merit, and reflected the utmost credit on the members and their conductor (Mr Higham). ${ }^{80}$

The next public appearance of this group was in May 1894, when it assisted at a concert by the visiting Australian violinist Bessie Doyle. ${ }^{81}$ She expressed her surprise at such a group existing in Hawera, and said it spoke with promise for the musical development of Hawera and the district. ${ }^{82}$ For its third concert in August 1894, it was noted that "The orchestra was stronger than on the occasion of its first performance, the addition of brass instruments having a decidedly good effect." 83 It then consisted of 15 players: nine violins, one viola, one cello, one double bass, a cornet and trombone, and a piano.

The fourth concert was in September 1895, and the net proceeds of $£ 8$ was donated to an unfortunate victim of a recent fire. ${ }^{84}$ The orchestra did not reappear until December 1896, when it assisted at a concert festival given by the touring Belgian-born violinist, Ovide Musin. This was its last appearance and no reasons have been found to explain why this seemingly successful and popular band ceased to exist. ${ }^{85}$

At the same time, Higham was working with his younger pupils and formed them into another orchestra, called, as was normal at the time, liliputian. ${ }^{86}$ The liliputian orchestra gave its first public concert in the Hawera Town Hall on 27 October 1894, and ceased public performances after July 1896. During this time it performed to general acclaim at Hawera, Manaia, and Normanby. It was again well supported by the Flynn and Connell families. It was not merely a vehicle for public concerts, but seems to have combined a mixture of educative and social occasions. At one such event held at his home, Higham reminded the young players in the orchestra that its value lay in providing amusement, instruction and experience, and he encouraged its members to be above all musically enthusiastic. ${ }^{87}$

Meanwhile, the surrounding districts were also gathering orchestral groups together, but at later times: Manaia and Stratford in 1894; Kaponga in 1900; and Eltham in 1903. Despite Higham's promising start in Hawera, by 1898 any specifically orchestral group had vanished. From then on, orchestral activity was limited to the small groups gathered together to accompany the 
activities of local operatic societies. The Hawera Orchestral Society was re-formed in 1914 when a series of patriotic concerts was given under the Anglican organist and choirmaster, Augustus Webb. But this too foundered after only three concerts. Early in 1921, another purely orchestral group was formed when the Hawera Male Voice Choir established an adjunct band. In August 1921, it was re-formed and renamed as the Hawera Orchestral Society, under a new conductor, Frederick Ollerenshaw. ${ }^{88}$ In 1922, this group gave a season of four concerts, including a concert performance of Wallace's opera Maritana. An additional event was a performance of Messiah with a choir of 200 voices on 30 November, when the Royal Wellington Choral Union assisted. And in 1923, the orchestral society presented another season of three concerts as well as a concert performance of Gounod's Faust. Despite enthusiastic and innovative work by Ollerenshaw, he lacked support from his own players, and in April 1924 he resigned. The arrival of Harry Fox at the end of 1924 saw a revival of the orchestral society under his leadership. This resulted in an increase in the playing numbers, which reached 60 in 1928, and he introduced closer links between the orchestra and the community, particularly with the school, as he gave the Hawera School Orchestra regular performing slots at the orchestral society concerts. He similarly forged new synergies with the local teachers by giving their top pupils exposure at the concerts too.

Before Ollerenshaw, conductors had been professional musicians, whereas he was a gifted amateur. This may indicate a rising level of musical competence in the local population, or that no other professional musician was prepared to assume this additional and onerous task, even if paid. Ollerenshaw's resignation was prompted by a reason all too common among orchestral bodies in both provincial and city activities. In its "World of Music" column, the Hawera \& Normanby Star summed up the situation: "no society can flourish without the hearty cooperation of the whole of its members, nor can a conductor be expected to retain his position unless members rally round him and show a keenness to succeed to back up the committee and conductor in the work of the society." 89

Orchestral groups generally formed after choral organisations, as finding a competent range of instrumentalists was far more difficult than assembling a group of people with vocal ability. Hawera's first orchestral group appeared in 1890, only twenty years after the town's settlement; a shorter time period than the establishment of orchestral groups in any of the four main centres. ${ }^{90}$ In size of orchestra, though, Hawera began smaller in comparison; not unexpected, given its lower population, but by the end of the 1920s it was surprisingly large, and on an even footing with those in the four main centres. ${ }^{91}$ The main cities had additional community orchestras active in the suburbs, and frequently had competing bodies for the same players when there were major orchestral groups active at the same time. ${ }^{92}$ In the number and frequency of orchestral groups, Hawera presents similarities to Christchurch, where, for example, in a 44year period from 1871 to 1914 there were five major groups formed. ${ }^{93}$ Hawera also had five groups formed in a similar period, 1890 to 1925.

Higham, though, brought Hawera to the forefront of innovation with the formation of the Hawera Ladies' Orchestra (1893-1896). Ladies' orchestras were a world-wide phenomenon at this time, and reflected the growing enfranchisement of women and their changing role in society. Making music had long been accepted as a gentile pastime for women, and many became exceedingly proficient performers in the acceptable areas of singing or piano playing; and as more formal tuition became available to women, there was a corresponding increase in the number who became highly skilled as string players. Employment opportunities were still prohibited to women in the all-male orchestras, and so professional ladies' orchestras became established in England, Europe and the United States. A major point of difference for New 
Zealand groups was the amateur nature of them; some members may have been professional music teachers, but work in the orchestra was unpaid. Ladies' orchestras in New Zealand began in Dunedin, where a local music teacher and furniture manufacturer, John Parker, presented one from 1882 to $1884 .{ }^{94}$ Professor Carl Schmitt in Auckland directed the longest running ladies' orchestra from 1888 to 1899 . Christchurch also had its own ladies' orchestra. ${ }^{95}$ Placed in the context of the development in New Zealand of ladies' orchestras, Higham's foray into this area was remarkable in its audacity, taking place as it did within such a small, isolated town.

Again, it was Higham who gave Hawera its own liliputian orchestra (1894-1896). Children's orchestras were a popular world-wide fashion begun in the 1870s and were in vogue for a number of decades, either based around a family or the pupils of a local music teacher. ${ }^{96}$ The Flynn family in Hawera provided the basis for Higham to add in his other pupils and enjoy an expanded group. Juvenile orchestras of pupils were a fairly common feature throughout New Zealand. $^{97}$

By 1931, when Higham died, a reinvigorated orchestral society was active, and there had been regular orchestral activity at the local cinema. The orchestral development in Hawera reflects a common state of musical affairs throughout New Zealand, as organised amateur music groups waxed and waned according to changing circumstances. This is further demonstrated by the situation in Hawera regarding choral groups.

\section{Choral Music}

The first choral group in Hawera was formed in 1880. Conducted by Sam Dixon and then Leslie Charles, it folded after only a year or two. ${ }^{98}$ Another society was formed in 1884, this time under the conductorship of the local bank manager, Charles Laishley, and it gave performances of some of the Savoy operas. ${ }^{99}$ After Laishley left in 1888, the society struggled on under the leadership of William Wanklyn, until in 1890 it too folded. ${ }^{100}$ In the vacuum left by the demise of this choral group, Higham formed the Hawera Musical Society in 1893, which operated as an amateur operatic group, and was able to muster eleven players for an accompanying orchestra. ${ }^{101} \mathrm{He}$ conducted two performances of Gilbert and Sullivan's The Pirates of Penzance in Hawera in September, with performances in Manaia and Stratford the following month. ${ }^{102}$ Higham was paid for his services with this group. ${ }^{103}$ In the following year, the conductor changed to Robert Foster while Higham led the orchestra; two further Gilbert and Sullivan comic operas were given, Patience and Yeoman of the Guard, including one performance in New Plymouth. In 1895, this group mounted The Mikado, in Hawera and New Plymouth. In 1896, Higham joined forces with another local, Horace Knight Baker, to form the Baker and Higham Liliputian Opera Company. ${ }^{104}$ Two performances of Planquette's Le Cloches des Corneville were given in February to mark the opening of the new Theatre Royal.

But the Hawera Musical Society foundered in 1896, and a new group called the Hawera Choral Society was formed. Higham had no association with the Hawera Choral Society, and when offered the conductorship of this group in 1898, he declined. This group also was short lived. It was noted by the erstwhile secretary of both these organisations, Stewart Fairhall, that they ceased owing "to want of financial support and patronage from the outside public, and partly to inefficient or unbusiness-like conductors." 105

Higham became actively involved in another public choral group in 1904, when another industrial exhibition was held in Hawera. Two choirs took part in an exhibition opening concert on 4 February; one was conducted by Robert Hutchens, and the other by Higham. It is highly likely these choirs were based around the groups each worked with in their respective churches, 
Hawera Methodist and St. Joseph's. Later in the same year a male voice choir formed, the Liedertafel, which gave a single public concert under John A. Jacob, before disappearing. ${ }^{106}$ It was re-formed in 1912, changed its name to Hawera Male Choir in 1915, and then proceeded to play a major role in musical development in the town. In addition to its concerts, it established the Hawera Competitions (1921), which became an important annual event; and promoted a local production of Gounod's Faust (1923).

In 1907 Higham formed another true community choral group: "It was decided to form a select choir to be called the Haydn Choir, and to give a series of light oratorio concerts on Sunday nights, the proceeds to go to the benefit of the hospital and other benevolent objects. The chief feature of the music will be the grand Masses of Haydn, Mozart, Gounod." 107 At the first concert in July, there were 18 singers, and an orchestra of $15 .{ }^{108}$ One Hawera resident was so pleased to see this happen he wrote to the local newspaper,

Will you allow me through the medium of your newspaper to personally thank $\mathrm{Mr}$ Joseph Higham and his choir for the very fine musical treat given us last night and to express a hope that it is only one of many such to follow. It seems a great pity that Hawera cannot support a permanent full choral society, there is ample talent here and it only requires bringing together. ${ }^{109}$

By its second concert in December the choir and orchestra had increased in size to a membership of $50 .{ }^{110}$ Over the next three years, this group gave two concerts per year with the last concert being on 5 August 1909. ${ }^{111}$ Higham did not attempt to establish any further choral groups after this, and any further work with the Catholic church after his resignation in 1904 was limited to choral work for special occasions only.

In 1906, a ladies' musical society was formed under the conductorship of Minnie Roe, and gave sporadic concerts which ceased when Roe left Hawera in 1915. The combination of this group and the Haydn Choir under Higham in 1908 was seen as providing Hawera with "the highest classes of choral music in existence." "112 Local music teacher Daisy Reilly formed a ladies' singing group as part of her annual pupils' concerts, and they included part songs and choruses. In 1922. the group comprised 30 performers. ${ }^{113}$ When she died in 1932, it was taken over by Annie Quin, who renamed it the Orpheus Choir.

\section{Brass Bands}

Conductors of brass bands were often paid for their services, and while not on the same scale as the pay for some church organists or conductors of other community musical groups, it did provide another form of income for appropriately experienced professional musicians. As early as 1874 the Oamaru Brass Band was offering the bandmaster a salary of $£ 50$, while the Wanganui Garrison in 1883 offered $£ 70$.

When the first brass band was formed in Hawera in June 1878, there was no retainer payment for the bandmaster. It began with 13 players, and did not make its first public appearance until the end of the year. Instruments were bought from subscription funds but even so, in late 1879 it was already in debt to the amount of $£ 18$, with the instruments being the property of "the township." From this beginning, a shortage of regular funds for support became a recurring problem for the Hawera Band. ${ }^{114}$ By 1884 the band ceased activity. A resurgence took place the following year, and Walter Hunter from Wanganui was appointed the bandmaster in early 1885 , but again no salary was available. ${ }^{115}$ In 1886 , the band was able to provide a salary of $£ 40$, and Henry Harbott was appointed, but resigned in April after only four months. ${ }^{116}$ It was noted that the band "has not possessed sufficient funds wherewith to retain the services of a 
paid bandmaster," and for a period of nearly seven years Tom Smart provided his services gratuitously. ${ }^{117}$ In 1892 the Band was able to give him an honorarium of $£ 10$, yet at the same time in the nearby township of Manaia, their bandmaster received £20. In 1893 at the Hawera Brass Band annual meeting, finances had improved to the stage where a paid bandmaster position was possible. Effusive thanks were given to Tom Smart for the stability he had provided over the years, and Higham was appointed Bandmaster at a salary of $£ 50 .{ }^{118}$

Unfortunately, it again fell into financial difficulties and in September 1896 was disbanded, owing money to the bank and to Higham. ${ }^{119} \mathrm{He}$ said he was forced to resign, as the lack of promised remuneration rendered his position untenable, and he had given up other financial possibilities to fulfil his band commitments. By October, though, he was in charge of a reformed group, which was initially called the Hawera Private Band, and later on referred to as the Old Hawera Band. Higham was most emphatic it was not to be called "Higham's Band."120 This band was in competition with the "official" band, the Hawera Borough Band, which had a new leader in Frederick Brunette. ${ }^{121}$ The two bands coexisted until late 1899, when efforts were made to resolve the difficulties posed by directing local resources towards two competing groups. ${ }^{122}$ A single band resulted, with neither Higham nor Brunette as bandmaster. ${ }^{123}$ While this was the end of Higham's direct involvement in the local band, he continued to provide a large amount of behind-the-scenes support and expertise, and was at times the conductor of the bands at Manaia, Stratford and Kaponga. ${ }^{124}$ He was proactive in his support for a wider regional organisation for brass bands, and in 1895 he attempted to form a West Coast Band Association, which was to comprise bands between Woodville and New Plymouth. ${ }^{125}$ He was unsuccessful, but his role in promoting a North Island Brass Band Association bore fruit, and in 1897 he was on the inaugural Committee. ${ }^{126}$ Over the next sixteen years, Higham was active with this association in a number of official roles including vice president (1904 and 1909), and as a committee member (1911-1913). In addition, he was called upon as a judge at band contests, notably in New Plymouth (1902) and Manaia (1912).

The Hawera Band was reorganised in 1914, and the name varied between Municipal Band and Borough Band. ${ }^{127}$ In 1915, following another reorganisation, the Hawera Citizens Band was formed, with the bandmaster to be paid $£ 65 .{ }^{128}$ Again, this group was unable to sustain activity every year, and in 1924, the Hawera Borough Council decided to support the re-formation of the Hawera Municipal Band. ${ }^{129}$ It was astutely noted by the local press in Hawera that the rise and fall of brass bands "is one of the calamities that spasmodically affect the smaller towns, where the bandsmen are volunteers and have to work for their living." ${ }^{130}$ The arrival of Harry Fox in 1924 was secured with an annual salary of $£ 200$, a large amount in comparison with other bands at this time, and possibly not quite the support the Borough Council had intended. His work paid off though, and by 1931 the band was within the ranks of the B Grade competitions. ${ }^{131}$

\section{Conclusion}

Higham married on 25 November 1901 at St. Mary of the Angels Church in Wellington, to Josephine Standish, who had also been born in Wigan. ${ }^{132}$ Both were advanced in years; he was forty-two and she was thirty-eight, and there were no children from the marriage. In 1922, they both returned to England on an extended trip. After a short illness, he died in Hawera Hospital on 4 November 1931, at the age of seventy-three. His wife died in 1944, and both are buried in the Hawera Cemetery. 
Higham's contribution to the early musical development of Hawera was extensive, and covered teaching, piano tuning, conducting, performing and composing. He worked with choral groups, orchestral groups, brass bands, and operatic groups. His most productive years in Hawera were the 20 years from his arrival in 1889, at the age of 31 , to 1909 , and during this period he was an undisputed leader in all the areas of music he took part in. Up until a few years before he died, he maintained a regular teaching practice at 87 Union Street, and continued to supply an orchestra to support local causes. Indeed, in 1924 his all-female Steel Guitar Orchestra performed at the Hawaiian-themed White Flower showing in the Opera House, including amongst other items an original composition by Higham. ${ }^{133}$

Along with his impressive range of musical activity, Higham demonstrated himself to be a forward-thinking musician, and advocated for a number of musical events intended to advance the cause of music. These included a festival for South Taranaki (1892), and an Eisteddfod in New Zealand (1909). ${ }^{134}$ His musical expertise was in demand for judging musical competitions other than brass bands, and included the Hawera Liedertafel (1914) and the Hawera Orchestral Society (1923). ${ }^{135}$ In addition to his entrepreneurial activity with his ladies' and liliputian orchestras, in 1901 he undertook the management of a concert tour by Katie Connell through Hawera, New Plymouth, Wanganui and Palmerston North. ${ }^{136}$

His long-standing and staunch support of the local Catholic church was balanced by him giving freely of his time and skills to support many other community endeavours. His devotion to the church was reflected in the many bequests he made to his local church and to other Roman Catholic groups, yet he also made generous allowances to his own family, including his unmarried sister Mary, and various nephews and nieces of his brothers. ${ }^{137}$ He gave extensive support to the formation and maintenance of Hawera Hospital. ${ }^{138}$

Surprisingly for such a public performer, his obituary noted that "He was a man of retiring disposition and took little part in public life, but he was held in high regard by his many friends." ${ }^{139}$ His contribution to his chosen place of work is summed up in his obituary, "Music in Hawera owes a very great deal to the late Mr Joseph Higham . . . [who] for many years ... was one of the leaders in musical circles." 140

"For its size, Hawera must be one of the most musical towns in the Dominion," reported Orpheus, the entertainment columnist for the Auckland Star: "It has three school bands and orchestras, a junior band of boys, a brass band, an orchestral society (70 performers), and a male choir." 141 Indeed, just three months prior to Higham's death, on August 10, 1931, Hawera heard a local performance of Mendelssohn's Hymn of Praise by a choir of 100 voices with full symphony orchestra. By 1931, support for music in Hawera was widespread and effective. ${ }^{142}$

Not all credit for this musical transformation cannot be given to Joseph Higham, but there is no doubt his early arrival in Hawera, and, more importantly, his long-term residence and solid application to musical affairs, had helped with the groundwork. As noted by Allan Thomas, "One answer to [Hawera's] distinctiveness comes from the quantity of music, rather than any special quality; another can be found in the particular combination of influential personalities who worked so assiduously in the musical field."143

There was also a pipe band and a military band in operation. ${ }^{144}$ In March 1931, the Taranaki Brass and Pipe Bands Association held a competition in Hawera, which was attended by eleven brass bands and three pipe bands. ${ }^{145}$ Musical competitions had been instigated by the Hawera Male Choir in 1921, and had become an important event in the annual musical calendar. Fox 
carried out impressive work with the secondary school students, and in 1929 the Hawera School Orchestra of 50 players travelled to Wellington, where they gave a concert in the Town Hall which was broadcast on 2YA. More than eighty years after Higham's death, he was still recognised as providing the basis for the later work by Fox: "It was the climate of making and enjoying music during Joseph Higham's years that ensured the success of the annual Hawera Competitions that began in the early 1920s and gave the remarkable H G A Fox a musically conscious population to build his bands and orchestras of the 1930s, 40s and 50s."146

Overall, the early musical life of Hawera covered the full range of activities carried out in the four main centres. There were differences, mainly of scale, reflected in the number of teachers, but more especially in the size of the pool of amateurs who made up the participants in the bands, choirs and operatic and orchestral activity. Indeed, as Margaret Bean observed of another provincial town, Ashburton, "The various musical societies, choral and instrumental, could depend only on a relatively small pool of long-term residents for both performers and audience. Enthusiastic newcomers to the town often promoted the formation of yet another group, only to see it struggle for survival in the competition for support." 147

While the role of Higham, Hutchens and Fox as professional musicians may appear to be unusual as none of them were primarily keyboard musicians, this was quite common, even in the four main centres. Indeed, the examples of Carl Schmitt (Auckland), Alfred Hill (Wellington), Frank Wallace (Christchurch), and Raffaello Squarise (Dunedin), confirm the ability of such well-trained musicians to become well-respected leaders of a wide range of local musical activity and organisation. And while the number of music teachers in Hawera was nowhere near those in the four main centres, this was a reflection of the vast difference in population. ${ }^{148}$ The quality and professionalism of Hawera's music teachers was well demonstrated by the full range of musical activities, plus the number of standout individuals who advanced to higher honours either nationally or even internationally.

As observed by John M. Thomson, "the quality of musical leadership remains the most important single factor in any consideration of music in the regions."149 Joseph Higham provides a fine example of quality leadership in his work in Hawera. 


\section{Appendix: Hawera Musicians Contemporary with Higham}

Edwards, Eleanor Mary (1875-1963), was born in Hokitika, the eldest of a family of four children, to the chemist Henry John Carruthers Edwards and Ellen Anne Coghlan. Her father died in 1889 and her mother remarried to John Parkin of Hawera in 1890. Around this time, Eleanor went to England and studied at the Ladies' College in Worcester, where she gained a certificate in music from the London College of Music. Upon her return to Hawera in 1894, she commenced teaching piano, painting and drawing, and in the following year was appointed the local representative for the London College of Music. For 1898 to 1899 she was joined in teaching by her younger sister Jane, and they styled themselves the Hawera School of Music and Art. She continued teaching alone after her sister's death in 1900, and left the district for England in 1914, with Mrs D. Goldfinch from Feilding taking over her teaching practice. While there was no public acknowledgement of her departure, a letter to the local press noted her quiet and painstaking teaching method along with a gentle and kindly manner. She did not appear as a public performer, even at her annual pupils' concerts, but she was a successful teacher, and her pupils entered the grade exams of the Associated Board, Trinity College and the London College of Music. Three gained the professional diploma ATCL; Miss M. Tayler (1905), Miss E. Johnson (1908), and Miss D. Paterson (1911). Following her departure from Hawera, Eleanor Edwards studied massage in England, and upon her return to New Zealand practiced this in Auckland, where she died in 1963.

Fairhall, Annie Florence, neé Palmer (1860-1945), was born in Australia, the daughter of Arthur Wellington Palmer and Elizabeth Ann Dodd. The family moved to the goldfields of New Zealand in late 1862, but were unsuccessful. Her parents parted in 1869, and Annie and her brother remained with their mother. Her father's mother had arrived in New Zealand in 1863, along with her second family from her remarriage, and Annie began to be associated with her two aunts in local concerts. She was then taken under the wing of her unmarried aunt, Clara Mary Straker, and by 1884 both were resident in Hawera. Here she established herself as the leading pianist in the locality with an extensive teaching practice and frequent performing and accompanying appearances. This included being the organist for the Anglican church of St. Mary's for over twenty years, the regular accompanist for the Hawera Choral Society, as well as the cellist in the Hawera Ladies' Orchestra. In 1891 she married Stewart Linwood Fairhall, a surveyor, and they had a family of three children. In 1906 the family moved to Nelson, Murchison, and then to Wellington in the early 1920s. Her eldest daughter, Kathleen, followed her mother in a musical career, and early instruction from her mother and Joseph Higham was succeeded by piano and violin study at the Nelson School of Music. Here she gained her LAB in 1913, and taught piano at the Nelson School of Music from 1916 until her marriage in 1925. Annie was divorced from her husband in 1926, and died in Wellington in 1945, at the age of 85 years.

Goodson, Mary Catherine "Katie," née Connell (1882-1958), was born in Hawera, the eldest of a family of 10 children. She was active in the church choir of St. Joseph's, and as a member of Joseph Higham's Liliputian orchestra. In 1896 at the opening of the new Theatre Royal she sang the role of Germain in a production by Baker and Higham's Liliputian Opera Company of Planquette's “Les Cloches des Corneville." In 1894 she was dux of the St. Joseph's School, the Convent of the Holy Infancy, and she then went to St. Mary's Convent, Wellington for her later schooling. Here she studied singing under Sister Mary Agnes, and won the Associated Board's Gold Medal for her senior grade singing in 1899, as well as achieving her Associate diploma from Trinity College, London. In 1901, Higham was her concert manager for a series of concerts in Hawera, New Plymouth, Wanganui, and Palmerston North. This concert tour was 
intended to be preliminary to her going to Australia and Europe to study, but in 1903 she married Matthew John Goodson, "and relinquished her chance of a brilliant concert-giving career for the more homely but practical occupation of making a colonist happy. ..." After marriage she moved to Auckland and Whangarei, where she sang in local oratorio productions. In 1912 the family moved back to Hawera, where she resumed her contribution as a regular guest at concerts by the orchestral society, the Operatic Society, and the Ladies' Musical Society. Her husband died in 1919, leaving her with a family of eight children. She died in Wellington on 2 July 1958.

Hutchens, Richard Lavars (1855-1919), was born in Penzance, Cornwall. He married Maria Giles Hoskings in 1879, and they immigrated to New Zealand where he worked as a bootmaker at Leeston. Seven children were born in Leeston, but only three survived; Will (1885), Jeannie (1890) and Francis (1892). They shifted to the Hawera district in late 1893, and in 1898 he announced his services as a teacher of music for "all kinds of wind and stringed instruments." He was appointed choirmaster of the Hawera Wesleyan Church in 1897, and under him the choir produced a number of well-received sacred cantatas. The church was central to his life and he was an accredited preacher and assumed a long-term leading role. All family members contributed to musical events, either singing, or playing musical instruments, and the Hutchens String Band appeared at many fundraising concerts. He was the early music teacher of all his children even though he never performed on the piano or organ in public. Will went on to study music, singing and violin at the Royal Academy in London, and received a Mus. Bac. from Canterbury College in 1919. Jeannie taught violin and piano in Hawera up to 1921 when she left the town. The youngest son, Frank, was the organist at their church from a very early age, and in 1905 went to the Royal Academy of Music in London to study. Richard was conductor of the Hawera Liedertafel from 1913 to 1917, and a member of the Manawatu Society of Professional Musicians. He died in 1919, and is buried in Hawera Cemetery, along with his wife who died in 1914.

Morrieson, Eunice Hyacinth, née Johnson (1889-1968), was born in New Plymouth to Charles Bartley Johnson and Lucy Ecclesfield. She was the eldest in a family of two girls and one boy. Many members of her mother's family were involved in music in Hawera, and her aunt, Bernice Ecclesfield, was a violinist in Joseph Higham's Ladies' Orchestra. Her father, a master carpenter and builder, crafted a violin for the 1904 Hawera Industrial Exhibition, where it was demonstrated by Violet Robinson. She attended the local schools, and gained a senior certificate from the district high school in 1905, at the same time learning music theory and piano from Eleanor Edwards. After gaining her ATCL in 1908, she commenced teaching and many of her pupils were successful in Associated Board and Trinity College examinations. In 1917 she married another local music teacher, Hugh Francis Morrieson. He had been born in the Shetland Islands, as was Eunice's father, and immigrated to New Zealand in 1895. He commenced teaching in Hawera in 1915, and after their marriage they both taught from their studio on the corner of Regent Street and South Road, a house that had been built by Charles Johnson. Hugh taught violin and cello while Eunice taught piano and harmony. He died of a heart attack in 1928, and Eunice became the sole means of support for the family resident in their home This included her six-year-old son, her unmarried sister Doris, and her father. She died on 16 November 1968 and is buried along with her husband in the Hawera Cemetery.

Quin, Annie Winifred, neé Flynn (1875-1955), was born in New Plymouth, the oldest of 10 children of John Flynn and Mary Jane Hall. They moved to Hawera in 1877, where her mother formed an orchestra using the talents of all 10 children. Annie played double bass, organ and piano, taught music, and was a conductor and composer. Throughout her long residence in 
Hawera she provided a fruitful and extensive contribution to its musical life. A major role in her musical activity was within the local Roman Catholic church, originally alongside her mother in the choir and as a member of the orchestra, but from the age of 16 she was the organist and on occasion had a number of her own compositions performed. The choir presented her with a gold watch in recognition of her work (1896), and a marble clock (1900). She married William Adolphus Quin on 9 November, 1901, attended by no fewer than five bridesmaids. While she ceased to be St. Joseph's organist upon her marriage, she continued all of her other musical activities. She taught organ and piano, played double bass in the Hawera Ladies' Orchestra and local orchestral societies up to 1943, and upon the death of Daisy Reilly in 1932, she assumed the role of conductor of the ladies' choir which she renamed to the Orpheus Choir. She was the regular accompanist for many local musical events and groups. All of this in addition to raising her own family of seven children. She died in 1955 and is buried in the Hawera Cemetery.

Reilly, Margaret Hilda Bennett "Daisy" (1883-1932), was born in Masterton, the oldest daughter of Bernard Reilly and Blanche Lucy Payne. Her mother died when Daisy was aged 11, and from the age of 12 she attended St. Mary's Convent School, Wellington. Here she was trained by Mother de Pazzi and Sister Mary Agnes in music. Daisy progressed through the grade exams of Trinity College, London, and the Associated Board, gaining her LAB in piano in 1901, while at the same time passing the senior grade for singing. After her schooling, she returned to Masterton and taught music at St. Bride's Convent. In January 1903 she moved to Hawera along with her father and younger sister Connie. From her first pupils' concert in November 1903, she was noted as a decided acquisition to music in Hawera, and these concerts became a notable feature in the musical calendar. There were regular successes in Trinity College and Associated Board examinations, with a number of her pupils advancing to professional diploma level in either piano playing or singing. Some achieved exceptional success; Maida Hooker won a scholarship to the Royal Academy of Music; Beatrice Horner won an Associated Board silver medal for piano, and Walter Fennell won a scholarship to the Royal Academy of Music for singing. Daisy conducted the St. Joseph's Choir from 1912 onwards, and was an active member of the Manawatu Society of Professional Musicians. She died on 6 September, 1932 and was farewelled with a Requiem Mass at St. Joseph's. She is buried in Hawera, along with Connie, who died in 1966.

Robinson, Violet Selina (1883-1965), was born in Patea, the eldest of a family of three girls to Reuben Robinson and Emma Old. She displayed precocious musical ability at an early age, and when a violin pupil of Joseph Higham was included in the Hawera Ladies' Orchestra in 1893. At their second concert in 1894, her playing as a member of a trio was noted as being "astonishingly clever for her years." She was also a member of Higham's Liliputian orchestra. In 1897 she went to England with her grandfather, John Jasper Wilson, where she pursued her musical studies, and passed examinations in violin and piano offered by the Victorian College of Music. Upon her return to Hawera, she commenced teaching violin and piano, styling herself Associate of the Victorian College of Music (AVCM). She lived for a time in Kaponga, where she was the director of the Kaponga Methodist Choir, as well as being conductor of the Kaponga Orchestral Society and the Manaia Orchestra. Her younger sister Ivy was also proficient on the violin and piano, and also taught music in Kaponga. Upon her return to Hawera, Violet continued to teach, with successful pupils in both the Associated Board and Trinity College exams. She was very active in concerts in smaller outlying areas of Hawera, and often appeared with her pupils at the small settlements of Mangatoki, Matapu, and Te Roti. She moved to Auckland, where her father died in 1930, and established a teaching practice called Balmoral School of Music. Violet died on Waiheke Island in 1965 and is buried in Auckland. 
Roe, Minnie, neé Dugdale (1873-1965), was born in England, the only child of John Pinder Dugdale and Eliza Ann Foden. The family shifted to New Zealand shortly after Minnie's birth, and her father had a long career in the Valuation Department. She married James Ninian Barrie in 1897, was divorced from him in 1903, and then married the architect Joseph Roe in 1904. There were two children from this marriage, and while her musical activity continued, it was in the localities that her husband moved for his work. She spent time in Masterton and Melbourne, before she arrived as Mrs Roe in Hawera in 1904. The family left Hawera in 1916 for Wanganui, and following time in Whangarei and Tauranga, she died in Auckland at the age of 91. At some stage Minnie returned to England where she studied piano for four years under Tobias Matthay, and gained her LRAM qualification. She continued study back in Wellington with Robert Parker and Thomas Trimnell, and was also a highly regarded organist and violinist. In 1894, when the Nelson School of Music opened, she was the foundation teacher of the piano, and also taught music at the Nelson Boys' and Girls' Colleges. She returned to teaching and performing in Wellington in 1896, and then went to Masterton in 1899, where she was organist at St. Matthew's church and formed and conducted the Masterton Ladies' Singing Club. In Hawera she taught violin, piano, singing and theory of music, as well as taking the St. Mary's Church Choir. She also founded and conducted the Ladies' Musical Society Choir, sometimes called the Liederkranz, which gave occasional concerts for fundraising, from 1906 to 1915, when she relinquished her role with it.

Swinburne, Catherine Barbara née St. Clair (1853-1942), was born in Birmingham, England, to George Horatio St. Clair and Elizabeth Yeoville Yardley Thomason. She married Walter London Swinburne in 1875, and they emigrated to Melbourne in early 1880. By early 1883 they were resident in Hawera, where she advertised her services as a teacher of music and singing, as well as giving classes in calisthenics and dancing. There is no indication of her own musical training, and while she performed in public as a pianist, it was as a vocalist that she became a mainstay performer at many community fundraising concerts. She took the title role in the cantata May Day with the Hawera Harmonic Society in 1884, and at the same concert appeared in a piano duet and singing songs. From then on she was a regular soloist in local operetta productions, including Trial by Jury (1885), Pirates of Penzance (1886 and 1893), Iolanthe (1887), and Martha (1888). Both Catherine and Walter held official roles in the Hawera Choral Society and took part in amateur dramatic productions. During the Taranaki Provincial Jubilee in 1891 they both contributed items at concerts in New Plymouth. They had a family of seven children, three born in England and four in New Zealand, yet this did not seem to hinder her ongoing musical involvement. The family returned to England for a visit in 1900, and upon their return in early 1901, removed to Wellington. At some stage the family became estranged from Walter, and he died alone in Taihape in 1920. She died in Wellington on 29 July 1942 at her home, 141 Abel Smith Street, having been predeceased by some of her children. 
${ }^{1}$ Elizabeth Nicol, "Transplanting Traditions: Immigrant Colonial Composers in New Zealand," in Searches for Tradition: Essays on New Zealand Music, Past and Present, ed. Michael Brown and Samantha Owens (Wellington, Victoria University Press, 2017), 26.

${ }^{2}$ Helen Watson, "Music in Christchurch" (master's thesis, Canterbury University College, 1948). Christopher Philip Prior Bornet, "Anglican Church Music in Canterbury 1850-1900." (master's thesis, University of Canterbury, 1973).

Brian W. Pritchard, "Societies in Society: A Case Study in the Historical Sociology of Music" (master's thesis, University of Canterbury, 1965.)

Philip Jane, "An Historical Survey of the Establishment of an Orchestral Tradition in Christchurch to 1939" (Ph.D. thesis, University of Canterbury, 2009).

Juanita M. F. Welsh, "George Frederick Tendall (1845-1901): The Career of a Professional Musician in Late-Victorian Christchurch" (master's thesis, University of Canterbury, 2004).

${ }^{3}$ Two notable exceptions are the biography of the Ashburton musician, Llewellyn Owen (Margaret Bean, A Passionate Affair: Llewellyn Owen and Music [Wellington: Steele Roberts Aotearoa, 2015]), and the history of the Nelson School of Music (Shirley Tunnicliff, Response to a Vision: The First One Hundred Years of the Nelson School of Music [Nelson: The School, 1994]). There have been brief summaries of musical activity in Paeroa, but these record mainly names of amateur participants (Ray Silcock and Edith Reid, "Early Musical History of Paeroa," Ohinemuri Regional History Journal 10 [October 1968]: 49); T. A. Moresby, "Music in Paeroa from 1908-1928," Ohinemuri Regional History Journal 11 [May 1969]: 18-21).

${ }^{4}$ Allan Thomas, "An Historical Ethnography of Music in the Town of Hawera in 1946: From the Recordings of the Mobile Unit of the New Zealand Broadcasting Service and Oral Histories of Musicians" (Ph.D. thesis, University of Otago, 2000). Allan Thomas, Music is Where You Find it: Music in the Town of Hawera, 1946: An Historical Ethnology (Wellington: Music Books New Zealand, 2004).

5 "Music in Hawera: A Few Notes on its History," Hawera \& Normanby Star, 8 July 1922, 9.

6 "Obituary," Hawera Star, 4 November 1931, 4.

${ }^{7}$ Auckland Star, 8 August 1931, 7.

8 "Obituary," Hawera Star, 4 November 1931, 4.

${ }^{9}$ Hawera \& Normanby Star, 7 December 1901, 2.

${ }^{10}$ The Cyclopedia of New Zealand: Industrial, Descriptive, Historical, Biographical, Facts, Figures, Illustrations: Taranaki and Hawke's Bay, free part, section 1 (Christchurch: The Cyclopedia Company, n.d.), 82-83.

${ }^{11}$ Taranaki Herald, 2 April 1887, 2.

${ }^{12}$ Taranaki Herald, 11 August 1887, 2.

${ }^{13}$ Taranaki Herald, 27 December 1887, 2.

${ }^{14}$ It has not been possible to discover what remuneration, if any, Higham received for his work in the church.

${ }^{15}$ Taranaki Herald, 4 May 1888, 3.

${ }^{16}$ Taranaki Herald, 15 March 1888, 2. No issues of this journal are extant, and there is no indication if there were any other issues after the first one.

${ }^{17}$ Taranaki Herald, 4 April 1888, 2.

${ }^{18}$ Taranaki Herald, 26 October 1888, 2.

${ }^{19}$ Taranaki Herald, 27 December 1888, 2.

${ }^{20}$ Taranaki Herald, 8 January 1889, 2.

${ }^{21}$ In 1891 the population of New Plymouth county was 11,255, compared with 5,631 in Hawera county. See

https://www3.stats.govt.nz/historic publications/1891-census/1891-results-census/1891-resultscensus.html, Table 20, Accessed on 15 February 2019.

${ }^{22}$ Hawera \& Normanby Star, 2 October 1891, 4.

${ }^{23}$ Taranaki Herald, 24 February 1879, 2; Hawera \& Normanby Star, 29 January 1881, 3.

${ }^{24}$ Hawera \& Normanby Star, 28 February 1896, 2.

${ }^{25}$ Hawera \& Normanby Star, 2 October 1895, 2. 
${ }^{26}$ Frederick Charles Sparks (1857-1913) was born in England and had training from the Royal Academy of Music in London. He was first noted in Patea (then called Carlyle) in late 1877, and he taught in and around Hawera and Wanganui. He died in Taihape in 1913 (Patea Mail, 12 September 1877, 1; Star, 13 October 1913, 6).

${ }^{27}$ Leslie Charles (1834-1890) was born in Australia and came to New Zealand in 1865. He toured throughout the country as a vocal member of various concert troupes, before settling in Patea in 1880 . He died in Dunedin in 1890.

Henry Homeyer (1832-1918) was born in London, and came to New Zealand in 1852. He was a violinist, pianist and piano tuner (Hawera \& Normanby Star, 18 December 1918, 4).

Bernard Homberg (1819?-1890) was born in Vienna, and came to New Zealand in 1872. He taught music in Greymouth and Wanganui prior to arriving in Patea in 1882. He was resident in Hawera from June 1882 until he left for Auckland in August 1884.

${ }^{28}$ See Appendix for a biography of Swinburne.

${ }^{29}$ See Appendix for a biography of Annie Palmer, under her married name Fairhall.

${ }^{30}$ Hawera \& Normanby Star, 11 February 1893, 2. Lucy Gertrude Harrison (1872-1955) arrived in Hawera in 1893 when her father, Edward Marmaduke Harrison, was appointed headmaster of Hawera School. Her older sister Eliza Winifred (1870-1931) was a proficient violinist as well, and both had been members of the Auckland Ladies' Orchestra conducted by Carl Schmitt.

${ }^{31}$ Hawera \& Normanby Star, 22 May 1924, 1.

${ }^{32}$ Hawera \& Normanby Star, 18 December 1895, 2.

${ }^{33}$ Richard Hutchens (Methodist, 1896-1919); Augustus Charles Webb (Presbyterian, 1913-1915); Hugh Reid (Presbyterian, 1915-1921); Leslie H. Goddard (Presbyterian, 1922-1924); and Harold C. Hillsdon-Hutton (Anglican, 1922-1923, and Methodist, 1923-1924).

${ }^{34}$ The installation of new larger organs in the main churches of Hawera often coincided with the arrival of a new organist. Both the Presbyterian and Anglican churches had Norman and Beard organs installed in 1913, and both had new organists within a year.

${ }^{35}$ See Appendix for a biography of Richard Hutchens.

${ }^{36}$ Hawera \& Normanby Star, 19 September 1924, 1. Harry Cecil Alderson Fox (1889-1960) was born in England and very early on followed a professional musical career. He came to New Zealand in 1911 to be the solo cornet player in the 10th North Otago Regiment Band (Taranaki Daily News, 28 July 2012, 16).

${ }^{37}$ See Appendix for a biography of Roe.

${ }^{38}$ See Appendix for a biography of Eleanor Edwards.

${ }^{39}$ Mary King was the wife of Henry William King, one of the early settlers in Hawera. Her role in music began when her husband died in 1914, and included private teaching, teaching music at a local private school, and a seven-year period as the Anglican church organist, 1914-1921.

${ }^{40}$ This group appears to be limited to Frederick Sparks (Royal Academy of Music); Minnie Roe (Royal Academy of Music); Eleanor Edwards (London College of Music); Violet Robinson (Victorian College of Music); and Hugh Reid (Royal College of Organists).

${ }^{41}$ See Appendix for biographies of Violet Robinson and Eunice Johnson, under her married name Morrieson.

${ }^{42}$ These included Daisy Reilly, L.A.B.; Eunice Johnson A.T.C.L.; Lynne Edwards, A.T.C.L. and L.A.B.; and Leo Whittaker, A.T.C.L. and L.A.B.

${ }^{43}$ These were Frank Hutchens (Royal Academy of Music, London); Will Hutchens (Royal Academy of Music, London); Maida Hooker (Royal College of Music, London); and Walter Fennell (Royal Academy of Music, London).

${ }^{44}$ Hazelden's school opened in 1914, with the organist at the local Anglican St. Mary's, Mrs. King, as music teacher. St. Mary's School opened in 1917, and in 1921 was advertising for a resident female music teacher (Hawera \& Normanby Star, 14 May 1921, 1).

${ }^{45}$ Katie and Winifred Connell, and Bessie Flynn are included in those who studied at St. Mary's in Wellington. It was the local pianist Maida Hooker who went to Timaru.

${ }^{46}$ Kirstine Moffat, Piano Forte: Stories and Soundscapes from Colonial New Zealand (Dunedin: Otago University Press, 2011), 170.

${ }^{47}$ Germans or Austrians who settled in Christchurch included Carl Bünz, Hermann Lund, Max

Hirschburg, and Richard Zimmermann, while Carl Schmitt and Ludwig Tutschka settled in Auckland.91 
Italians included Raffaello Squarise in Dunedin and Salvatore Cimino and Alfred Truda in Wellington. François Cailliau from France settled in Auckland.

${ }^{48}$ Moffat, Piano Forte, 164.

${ }^{49}$ A quarter or a term usually consisted of 26 weeks, and lessons were often given as two half-hourly lessons, or one full hour per week. Fees were less if the lesson was for group instruction. A number of teachers in Hawera visited pupils at their home to give lessons.

${ }^{50}$ In Christchurch in 1885, the visiting English teacher of piano and singing, Cecilia Summerhayes, asked for two to five guineas per quarter (see The Press, 24 January 1885, 3). And in 1896, the conductor and violinist Frank Wallace set his fees to four guineas per quarter (see The Press, 25 May $1896,1)$.

${ }^{51}$ These salaries were within the Anglican church, and were those for John Alexander Beale at St. Mary's Cathedral in Auckland (1889), and George Tendall at the Christchurch Cathedral (1885). The big churches offered the higher salaries, and by 1900, 1100 per annum was the standard payment for the organists at the Presbyterian churches of St. John's (Wellington), First Church and Knox Church (both Dunedin), and the Anglican churches of St. Paul's (Dunedin), and St. Peter's (Wellington).

${ }^{52}$ Helen Watson, "Music in Christchurch" (master's thesis, Canterbury University College, 1948), 48.

${ }^{53}$ In the early 1900s in Auckland, payments ranged from $£ 40$ at St. John's Methodist to $£ 50$ at St.

David's Presbyterian. And likewise in Dunedin, where there was a similar salary at St. John's Roslyn, Green Island Presbyterian.

${ }^{54}$ The church had only opened in June 1887 (New Zealand Tablet, 8 July 1887, 18).

${ }^{55}$ New Zealand Tablet, 4 October 1889, 13.

${ }^{56}$ Hawera \& Normanby Star, 28 December 1892, 2; New Zealand Tablet, 30 April 1897, 19.

${ }^{57}$ Frances Porter, "Annie Quin," in The Book of New Zealand Women, ed. Charlotte Macdonald, Merimeri Penfold, and Bridget Williams (Wellington: Bridget Williams Books, 1991), 541-43. See Appendix for a biography of Annie Quin.

${ }^{58}$ See Appendix for a biography of Katie Connell under her married name Goodson.

${ }^{59}$ Hawera \& Normanby Star, 7 December 1901, 2.

${ }^{60}$ Indeed, Katie Connell was dux in 1894 (Hawera \& Normanby Star, 19 December 1894, 2).

${ }^{61}$ New Zealand Tablet, 12 July 1889, 18; New Zealand Tablet, 14 December 1894, 8; Taranaki Herald, 26 February 1895, 2; New Zealand Tablet, 29 December 1898, 20; Hawera \& Normanby Star, 9 January 1900, 2.

${ }^{62}$ New Zealand Tablet, 1 March 1895, 15.

${ }^{63}$ New Zealand Tablet, 26 December 1901, 13.

${ }^{64}$ Hawera \& Normanby Star, 28 December 1892, 2; New Zealand Tablet, 26 April 1895, 15; New Zealand Tablet, 15 January 1897, 8; New Zealand Tablet, 26 December 1901, 13.

${ }^{65}$ Hawera \& Normanby Star, 7 December 1901, 2.

${ }^{66}$ New Zealand Tablet, 23 July 1903, 5. In addition to her role in St. Joseph's Choir, Catherine Espagne had been active in Hawera as a pianist and viola player. See Appendix for a biography of Daisy Reilly.

${ }^{67}$ Hawera \& Normanby Star, 13 July 1904, 3.

${ }^{68}$ Hawera \& Normanby Star, 13 July 1904, 3.

${ }^{69}$ T. E. Muir, Roman Catholic Music in England, 1791-1914: A Handmaid of the Liturgy? (Aldershot: Ashgate, 2008). 185-87. This section discusses the reasons for the changes, and implications. Also see

"Tra le Sollecitudini: Instruction on Sacred Music," www.adoremus.org/MotuProprio.html, accessed 15 February 2019.

${ }^{70}$ A long-standing conductor and choirmaster at St. Mary's was Philip Putnam, and after his death in 1890, Salvatore Cimino. The leader of the orchestra was the local violinist, Daniel MacDuff Boyd. All three positions were paid, but the level of remuneration was not generally as well publicised as for Anglican and Presbyterian positions.

${ }^{71}$ New Zealand Tablet, 13 March 1896, 16.

${ }^{72}$ New Zealand Tablet, 8 March 1895, 13; New Zealand Tablet, 20 November 1902; New Zealand Tablet, 18 December 1902, 4.

${ }^{73}$ Hawera \& Normanby Star, 14 November 1912, 4.

${ }^{74}$ Patea Mail, 25 August 1877, 3. A cornopean was a valved brass instrument, similar to a cornet.

${ }^{75}$ Patea Mail, 30 March 1883, 3.

${ }^{76}$ New Zealand Herald, 12 December 1890, 3. 
${ }^{77}$ New Zealand Herald, 6 July 1891, 6.

${ }^{78}$ Hawera \& Normanby Star, 25 May 1893, 2.

${ }^{79}$ Hawera \& Normanby Star, 15 December 1893, 2.

${ }^{80}$ Hawera \& Normanby Star, 7 April 1894, 2.

${ }^{81}$ Born in Melbourne, Australia, Lydia Elizabeth Doyle (1873-1937) studied for a number of years at the Leipzig Conservatory with Hans Sitt. She married Louis Reginald Northey during her 1894 tour of New Zealand. She died in the United States.

${ }^{82}$ Hawera \& Normanby Star, 2 May 1894, 3.

${ }^{83}$ Hawera \& Normanby Star, 25 August 1894, 2.

${ }^{84}$ Hawera \& Normanby Star, 10 October 1895, 2.

${ }^{85}$ Two of its foundation members, Lucy and Eliza Harrison left Hawera in 1895, and this may have been a contributing factor. They returned to Auckland with their father when he retired from school teaching.

${ }^{86}$ More commonly spelt "Lilliputian," this term was coined by the novelist Jonathan Swift in his 1726 book Gulliver's Travels. It refers to a miniature people who stood about six inches tall.

${ }^{87}$ Hawera \& Normanby Star, 9 June 1896, 2.

${ }^{88}$ Frederick Hurstfield Ollerenshaw (1913-1960) ran a private hotel from 1918 to 1923, and then the "Golden Minim" tea rooms. He was a playing member of the local brass band and in 1924 was the musical director of the Hawera Operatic Society.

${ }^{89}$ Hawera \& Normanby Star, 26 April 1924, 8.

${ }^{90}$ Auckland: founded 1840, first orchestral group 1881, 41 years; Wellington: founded 1840, first orchestral group 1882, 42 years; Christchurch: founded 1850, first orchestral group 1871, 21 years; Dunedin founded 1848, first orchestral group 1883, 35 years.

${ }^{91}$ In the 1890s, Hawera, with a group of 13 players, was less than a quarter of the size of the Dunedin Orchestral Society, which then had 57 players. By 1928 though, its reported strength of 55 players was similar to that of the inaugural concert from the Wellington Symphony Orchestra. See Evening Post, 2 June 1928, 25; and Evening Post, 23 October 1928, 5.

${ }^{92}$ In Auckland there were the Auckland Amateur Orchestral Society and the Auckland Orchestral Union active together, 1889-1890. Similarly in Christchurch with the Christchurch Orchestral Society and the Christchurch Symphony Orchestra, 1916-1920. And in Dunedin, with the Dunedin Orchestral Society and the Dunedin Philharmonic Society, 1904-1932.

${ }^{93}$ Orchestral Society (1871-1878); Amateur Orchestral Society (1879-1889); Orchestral Society (1891-1893); Musical Union (1894-1912); Orchestral Society (1908-1939).

${ }^{94}$ John Thomas Bowley Parker (1833-1902) was an active music teacher as well as a furniture manufacturer in partnership with his sons. The ladies' orchestra was based around his own family, being led by his daughter Sarah.

${ }^{95}$ The Star, 22 October 1898, 5. Founded in 1898 by Freda Marsden, it presented public concerts for a couple of years, and at times consisted of 22 players, mainly of strings, but including a number of wind, brass and tympani.

${ }^{96}$ Family orchestras in New Zealand included those of the Corrick, Black and Hutton families. Both the Corrick and Black families performed in Hawera; the Corrick Orchestra in 1900, and the "Musical All Blacks" in 1903. See Hawera \& Normanby Star, 17 August 1900, 3; Hawera \& Normanby Star, 23 October 1903, 2.

${ }^{97}$ Good examples are those of Freda Marsden in Christchurch (1897-1906), and Mary Harding in Auckland. Harding managed to assemble an orchestra of 40 players in 1894. New Zealand Herald, 4 December 1894, 4.

${ }^{98}$ Hawera \& Normanby Star, 3 July 1880, 3; Hawera \& Normanby Star, 13 July 1914, 5.

${ }^{99}$ Hawera \& Normanby Star, 12 February 1885, 2. Under Laishley, they performed HMS Pinafore (1884), Pirates of Penzance (1886), and Iolanthe (1887).

${ }^{100}$ William Henry Endell Wanklyn (1858-1927), was an accountant and town clerk of Hawera up to 1890 when he was appointed secretary of the Canterbury Jockey Club. His departure from Hawera was probably the reason the Choral Society ceased.

${ }^{101}$ Hawera \& Normanby Star, 1 November 1894, 2.

${ }^{102}$ Hawera \& Normanby Star, 24 March 1893, 2. 
${ }^{103}$ Hawera \& Normanby Star, 26 May 1894, 2. The amount of his salary is unknown, but he generously did not claim the entire amount he was owed.

${ }^{104}$ Horace Knight Baker (1868-1931) was the only son of Horace Romano Baker, an upholsterer and astute businessman of Hawera. The father had been a member of a military band in the English army and was an important committee member of the early Hawera Brass Band. Horace Knight and his wife both took an active interest in the Hawera Dramatic Society as well as the Hawera Musical Society. Both took leading roles in The Yeoman of the Guard (1894), and Horace generally painted the scenery backdrops as well as being stage manager.

${ }^{105}$ Hawera \& Normanby Star, 1 August 1903, 2.

${ }^{106}$ Hawera \& Normanby Star, 20 October 1904, 3. The conductor, John Attwood Jacob, was appointed vicar of St. Mary's church in 1902, taking up the position from England. In 1908 he was appointed to Christ Church in Wanganui. The accompanist at this first concert was Leo Whittaker.

${ }^{107}$ Hawera \& Normanby Star, 4 April 1907, 4.

${ }^{108}$ Hawera \& Normanby Star, 1 July 1907, 7.

${ }^{109}$ Hawera \& Normanby Star, 1 July 1907, 7.

${ }^{110}$ Hawera \& Normanby Star, 16 December 1907, 4.

111 This was as a benefit concert for local musician Will Hutchens, prior to his leaving to study at the Royal Academy of Music in London.

${ }^{112}$ Hawera \& Normanby Star, 11 March 1908, 6.

${ }^{113}$ Hawera \& Normanby Star, 15 December 1922, 5.

${ }^{114}$ Patea Mail, 24 September 1879, 2.

${ }^{115}$ Walter Ratcliffe Hunter (1852-1927) was noted as "in his time one of the most noted bandsmasters in New Zealand" (New Zealand Herald, 1 April 1927, 12). His time in Hawera was very brief and was a matter of months only between Hunter's work in Wanganui and then Auckland. His primary occupation in Wanganui was as a tobacconist, which was not very successful, as he had sued for bankruptcy in 1884.

${ }^{116}$ Henry James Harbott (1843-1905) was born in England and had his musical training in the British Army. He was the bandmaster for the Marton Brass Band, established the Palmerston Brass Band in 1881, and continued after Hawera at Woodville and then in Wellington.

${ }^{117}$ Hawera \& Normanby Star, 3 July 1886, 2. Tom Smart (1856-1945) was a local carpenter and joiner and late in life was publican in a number of local hotels. He married Ada Mabel Beamish in 1892. Two of her brothers, Ernest (cornet), and Hector (flute), were members of Higham's liliputian orchestra.

${ }^{118}$ Hawera \& Normanby Star, 23 March 1893, 2.

${ }^{119}$ Hawera \& Normanby Star, 5 September 1896, 2.

${ }^{120}$ Hawera \& Normanby Star, 4 January 1897, 2.

${ }^{121}$ Frederick William Brunette (1860-1951) was the eldest son of John Brunette, a watchmaker and jeweller in Hawera. Born in England, he was a skilled bandsman and cornet player, and was the bandmaster of the Newmarket Brass Band in Auckland in 1892. Following the early death of his wife he returned to Hawera and for a salary of $£ 40$ was appointed bandmaster of the Hawera Brass Band in 1896. Hawera \& Normanby Star, 16 October 1896, 2.

${ }^{122}$ Hawera \& Normanby Star, 20 June 1899, 2.

${ }^{123}$ The new Bandmaster was T. H. Hughes, who had been in charge of the Stratford Band from 1892 onwards. Hawera \& Normanby Star, 30 October 1899, 2.

${ }^{124}$ Taranaki Herald, 8 May 1891, 2.

${ }^{125}$ Wanganui Herald, 18 April 1895, 2; Feilding Star, 10 April 1895, 2.

${ }^{126}$ Evening Post, 10 February 1897, 4.

${ }^{127}$ Hawera \& Normanby Star, 13 October 1914, 1.

${ }^{128}$ Dominion, 10 April 1915, 1.

${ }^{129}$ Hawera \& Normanby Star, 26 August 1924, 4

${ }^{130}$ Hawera \& Normanby Star, 29 March 1924, 6.

${ }^{131}$ Eventually the Hawera Municipal Band achieved the pinnacle of brass band playing in New Zealand by winning the 1951 National Brass Band Competition. They were conducted by Louis Fox, the son of Harry Fox.

${ }^{132}$ Hawera \& Normanby Star, 28 November 1901, 2.

${ }^{133}$ Hawera \& Normanby Star, 2 August 1924, 16. 
${ }^{134}$ Hawera \& Normanby Star, 25 February 1892, 3; Hawera \& Normanby Star, 14 April 1909, 6.

Neither suggestion came to fruition, although a number of meetings were held and a committee was formed and a budget proposed for the Festival.

${ }^{135}$ In 1914, when Higham was the judge of a quartette competition instigated by the Hawera Liedertafel, he again raised his thoughts on the benefits of an Eisteddfod. See Hawera \& Normanby Star, 18 June 1914, 7; Hawera \& Normanby Star, 19 October 1923, 7.

${ }^{136}$ Hawera \& Normanby Star, 25 February 1901, 3.

${ }^{137}$ In 1910 he had sponsored the immigration to New Zealand of his younger sister, and she lived nearby in Waitara. Two of his nieces, Ellen and Mary, lived close at hand in Eltham.

${ }^{138}$ Stratford Evening Post, 21 January 1927, 4.

${ }^{139}$ Obituary. Hawera Star, 4 November 1931, 4.

${ }^{140}$ Hawera Star, 7 November 1931, 15.

${ }^{141}$ Auckland Star, 8 August 1931, 7.

${ }^{142}$ Evening Post, 29 August 1931, 17. An anonymous donation of $£ 100$ was given to the Main School to assist with instruments and tuition.

${ }^{143}$ Allan Thomas, Music is where Where you find Find it: music in the town of Hawera, 1946: an historical ethnology, (Wellington: Music Books New Zealand, 2004.) p., 27.

${ }^{144}$ Stratford Evening Post, 12 March 1930, 5.

${ }^{145}$ Stratford Evening Post, 21 March 1931, 7.

${ }^{146}$ Taranaki Daily News, 20 October 2012, 16.

${ }^{147}$ Bean, A Passionate Affair, 23.

${ }^{148}$ Relative populations taken from the 1930 yearbook,

http://archive.stats.govt.nz/browse for stats/snapshots-of-nz/digital-yearbook-collection.aspx:

Auckland city, 213,330; Wellington city, 138,510; Christchurch city, 126,040; Dunedin city, 85,420; Hawera county, 10,095.

${ }_{149}$ John Mansfield Thomson, The Oxford History of New Zealand Music (Auckland: Oxford University Press, 1991), 51. 